\title{
全身性エリテマトーデス患者に生じた声帯結節と 竹節状声帯に対する音声治療の経験
}

\begin{tabular}{|c|c|c|c|c|}
\hline 近藤 & (1) & 水田 & 匡信 ${ }^{2)}$ & 楯谷 一郎 ${ }^{11}$ \\
\hline 末廣 & 篤 ${ }^{1)}$ & 岸本 & 曜1) & 曽我美 遼1) \\
\hline 石田 & 愛1) & 倉智 & 雅子3) & 大森 孝一 11 \\
\hline
\end{tabular}

要 約：声帯結節と竹節状声帯を呈した全身性エリテマトーデス (systemic lupus erythematosus: SLE) 例を経験した。症例は 29 歳女性. 嗄声を認め当科受診した。声の酷使 があり喉頭所見では両声帯膜様部中央に声帯結節を認めたほか，それとは別に膜様部中央と声 带突起のほぼ中間に乳白色状の竹節状の結節を認め, ストロボスコピーで左右位相のずれ, 声 門上部の前後径短縮が見られた。音声治療を実施したところ器質的病変に顕著な変化は見られ なかったが, 自覚的・他覚的に嗄声が改善した。

本症例の機序として, 声の酷使によってまず声帯結節が膜様部中央に出現し，そのため声帯 結節のある声帯膜様部中央と声帯突起のほぼ中間部の振動が大きくなり, 免疫複合体が沈着し て竹節状の結節が出現したと考えられた。音声治療は竹節状声帯への直接的な効果は期待でき ないが，声の酷使など機能性要因がある場合は積極的に考慮すべきと考えられた。

索引用語：全身性エリテマトーデス, 竹節状声带, 声带結節, 音声治療

\section{Voice Therapy for a Patient with Systemic Lupus Erythematosus Presenting Bamboo Nodes and Vocal Fold Nodules —A Case Report——}

Kanako Kondo $^{1)}$, Masanobu Mizuta ${ }^{2)}$, Ichiro Tateya ${ }^{11}$, Atsushi Suehiro ${ }^{1)}$, Yo Kishimoto ${ }^{11}$, Toru Sogami ${ }^{1}$, Ai Ishida ${ }^{1)}$, Masako Fujiu-Kurachi ${ }^{3)}$ and Koichi Omori ${ }^{1)}$

\begin{abstract}
The authors experienced a case of vocal fold bamboo nodes which appeared along with vocal nodules in a 29-year-old woman who was diagnosed as systemic lupus erythematosus (SLE). The patient visited our outpatient clinic complaining of hoarseness. She exhibited a strong tendency of daily vocal abuse. An initial flexible laryngeal endoscopic
\end{abstract}

京都大学大学院医学研究科耳鼻咽喉科・頭頸部外科 ${ }^{11}$ ： ₹ 606-8507 京都市左京区聖護院川原町 54

倉敷中央病院耳鼻咽喉科 ·頭頸部外科 ${ }^{2)}$ : ₹ 710-8602 岡山県倉敷市美和 1-1-1

国際医療福祉大学成田保健医療学部言語聴覚学科 ${ }^{3)}$ : 干286-8686 千葉県成田市公津の杜 4-3

${ }^{1)}$ Department of Otolaryngology-Head \& Neck Surgery, Graduate School of Medicine, Kyoto University: 54, Kawahara-cho, Shogoin, Sakyo-ku, Kyoto 606-8507, Japan

${ }^{2}$ Department of Otolaryngology-Head \& Neck Surgery, Kurashiki Central Hospital: 1-1-1, Miwa, Kurashiki, Okayama 710-8602, Japan

${ }^{3}$ Department of Speech and Hearing Sciences, School of Health Sciences, Narita Campus, International University of Health and Welfare: 4-3, Kozunomori, Narita, Chiba 286-8686, Japan

2019 年 6 月 3 日受稿 2019 年 9 月 24 日受理 
examination revealed bilateral vocal fold nodules in the middle portion of the vocal folds and bilateral white bamboo nodes in the posterior third portion of the vocal folds. Stroboscopic examination showed asymmetrical vibratory phases of the mucosal wave and mild anteroposterior narrowing of the supraglottic space. To treat her functional problems, voice therapy was provided. Post-therapy examination demonstrated improvements in both selfevaluation and instrumental/clinical measures, although the vocal lesions remained the same.

The causes of the bamboo nodes in this patient are suspected as follows: 1) The patient's vocal abuse caused vocal nodules in the middle portion of the vocal fold mucosa. 2) The presence of the vocal nodules increased the vibration of the membranes between the nodules and the process. 3) The increased vibration led to accumulation of immune complexes and subsequent bamboo nodes in the posterior third of the membranous vocal folds. This case report indicates that, in patients with SLE, although voice therapy does not solve the organic aspects of the problems, it is important for identifying functional components of the voice problems. We therefore view voice therapy as a valuable treatment option.

Key words: systemic lupus erythematosus, bamboo nodes, vocal fold nodules, voice therapy

\section{はじめに}

自己免疫疾患例の喉頭症状の一つに竹節状声带が挙 げられる。竹節状声带では両声帯膜様部に帯状の隆起 性病変が認められ，この隆起性病変は自己免疫複合体 の沈着と考えられており ${ }^{1)}$, 多くは膜様部中央に発現 する．声の酷使との関連も指摘されており ${ }^{1,2)}$ ，その 発現機序は両声帯の接触刺激 (contact) によるもの ではなく, 声帯の振動様式そのものの影響を受け，免 疫複合体が中央に集合し沈着するためと推察されてい る. 今回, 両声帯膜様部中央の声帯結節とともに, そ の背側に竹節状の結節を呈した全身性エリテマトーデ ス (systemic lupus erythematosus: SLE) 症例の発現 機序について Hosako-Naito ら ${ }^{1)}$ の仮説を支持するも のであったこと, 加えて音声治療が有効であったこと を，文献的考察を加えて報告する。

\section{症例}

症例は 29 歳女性．騒音下での勤務（工場）と育児 のため，発声に負荷が掛かり，声を酷使する状態が続 いていた。

既往歴：26 歳時に関節痛，倦㤐感等を主訴に免疫 内科を受診し，SLEと診断を受けたＳLEの疾患活 動性を評価する指標 SLEDAI（Systemic Lupus Erythematosus Disease Activity Index $)^{3)}$ は発症後か ら音声治療後まで 4〜5点の間を推移している. SLEDAI では SLE の活動性が軽いレベルは 1〜 点の 指標で，本症例は活動性レベルが低い状態が続いてお
り、そのためステロイド治療はせずに経過観察を行っ ていた。

現病歴：28 歳時に嗄声と喉頭違和感を訴え, 当科 を受診した。喉頭内視鏡検査では，両声带膜様部中央 に結節性病変を認めた。結節性病変とは別に，さらに その背側に乳白色状, 横断性の病変を認め, SLEに 伴う竹節様の病変が疑われた。竹節様の病変は左右同 位置ではなく，左声带の病変は声帯膜様部中央の結節 性病変と声带突起の中間にあり, 右声带の病変は左の 病変に比べ，より背側に位置していた（図 1)。ス卜 ロボスコピー検査では，声帯結節（矢印で示す部分） を境に声帯振動が異なった。声帯前方はほとんど振動

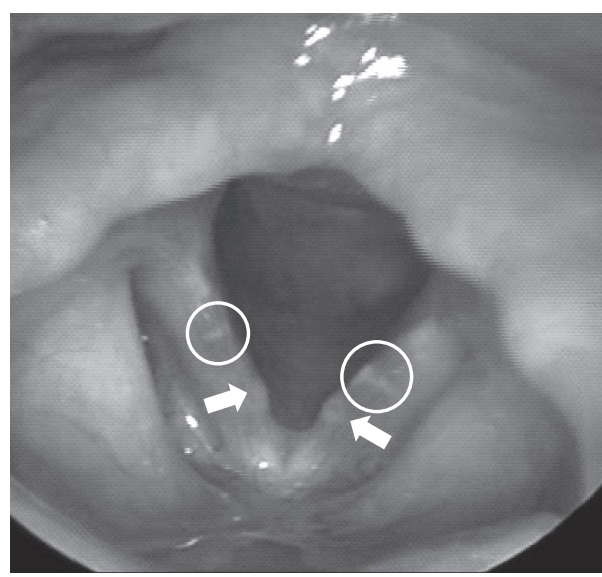

図 1 音声治療前の喉頭所見 両声帯膜様部中央に声帯結節（矢印で示す部 分）を，膜様部中央と声帯突起のほぼ中間に 乳白色状の竹節様の病変 (丸で囲った部分) を認めた。 
音声治療前 $\mathrm{A}$

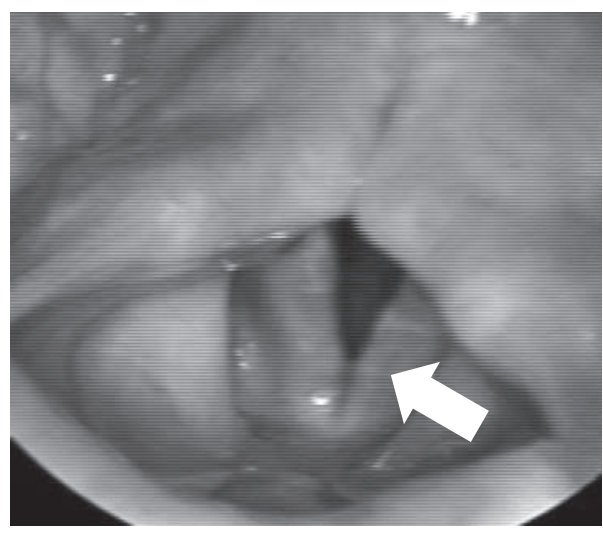

A-1

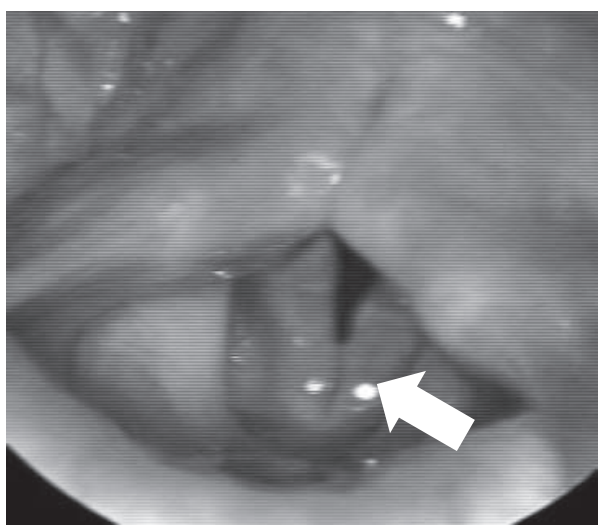

A-2

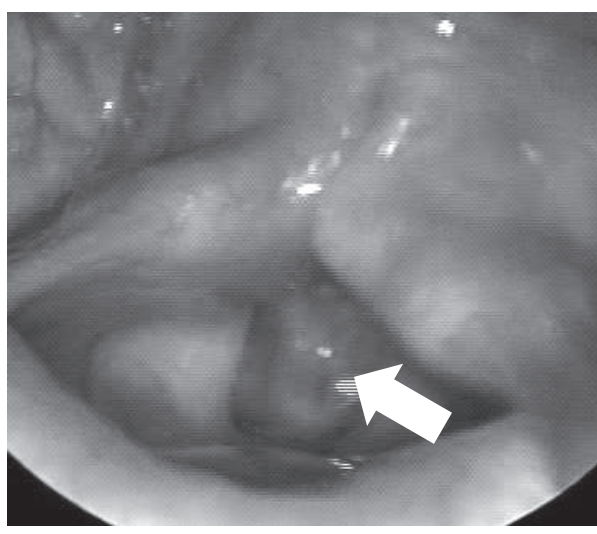

A-3
音声治療後 B

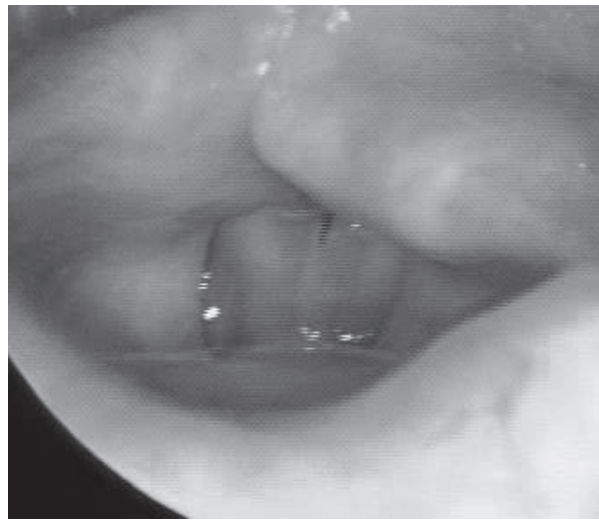

B-1

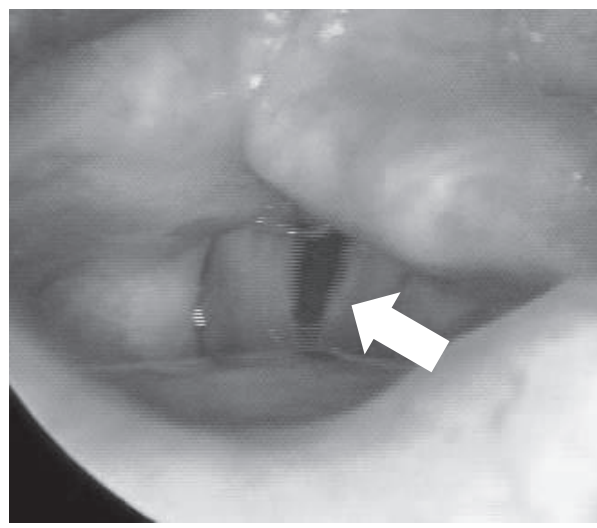

B-2

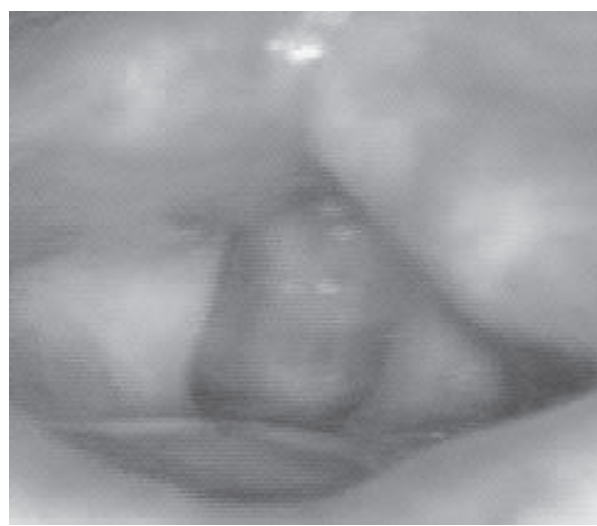

B-3

図 2 音声治療前・後のストロボスコピー

A-1～3 は音声治療前, B-1〜3は音声治療後のストロボスコピーを示す. 音声治療前は声帯結節 (矢 印で示す部分）を境に声帯振動が異なった。声帯前方はほとんど振動が認められない. 声帯後方 の振動が 1 3 の順に開放期・閉鎖期があるのが認められた。音声治療後は声帯粘膜振動の増幅 が見られ，声帯結節（矢印で示す部分）を境にした声帯前方も振動が生じた。

が認められず，声帯後方に声帯粘膜振動が認められた (図 2A)。 。た, 粘膜振動の位相差が生じる場合もあっ た. 加えて, 過緊張性発声を疑う声門上部の前後径短 縮も認められた。聴覚心理的評価はG2R1B2A0S0, 最長発声持続時間（MPT）は 14.5 秒, 空気力学的検
査による平均呼気流率（MFR）は $176 \mathrm{ml} /$ 秒，音響 分析による基本周期変動指数（pitch perturbation quotient: PPQ）は $3.80 \%$, 振幅変動指数（amplitude perturbation quotient: $\mathrm{APQ}$ ）は $11.26 \%$ ，倍音に対す る雑音の割合 (noise-to harmonic ratio: NHR) は 0.30 
表 1 音声治療前後の音声検査結果

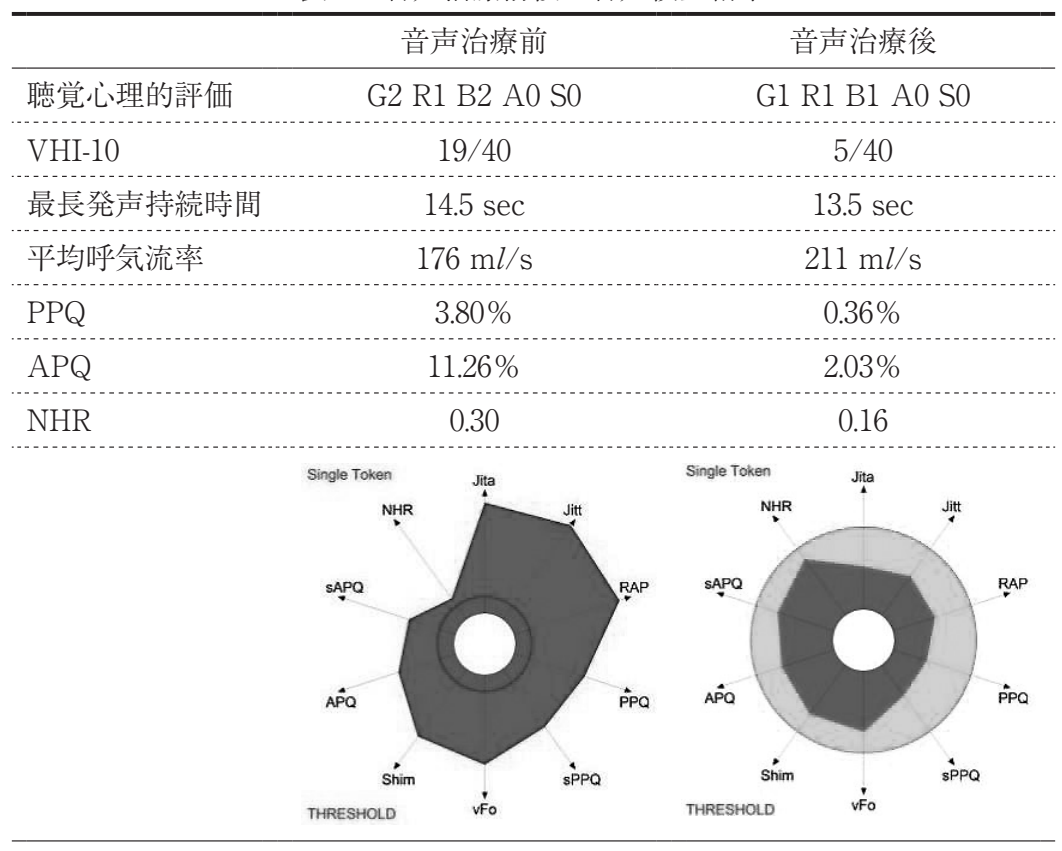

であった。自覚的評価によるVHI-10（Voice Handicap Index-10）は 19 点であった（表 1).

問題点：上記の結果より，本症例では声带結節と竹 節状の結節が合併しており, これらの病変による声带 粘膜波動減弱と左右位相のずれが嗄声を出現させる問 題点と考えられた。さらに器質的病変（声带結節・竹 節状の結節）の成因の背景には声の酷使や過緊張性発 声といった䛊った発声行動様式や発声方法の存在が推 測され ${ }^{1,3-5)}$ ，このような機能性要因が嗄声出現の根本 的な問題であると判断した。

治療方針：上記問題点から, 根本的な機能性要因 (声 の酷使や過緊張性発声）に対する治療として，まず音 声治療を実施し，改善を得られない場合はステロイド 声帯内注射を行うこととした，2つ目の治療方針をス テロイド声帯内注射と選択した理由としては，切除手 術は侵襲性があり，SLEの活動レベルが低く安定し ている本症例にとってステロイド内服治療は避けるほ うがよいと考えたためだった。

音声治療内容：誤った発声の行動様式を改善させる こと, 発声様式の是正として声帯粘膜波動の増大・共 鳴腔の拡大による発声効率の向上を目指し，1クール (3 カ月), 月に約 1 回，計 4 回実施した。内容として は(1)声の衛生指導, (2) Guzman らの報告に準じた water resistance therapy ${ }^{6,7}$ ) (口径 $10 \mathrm{~mm} \times$ 長さ 21 $\mathrm{cm}$ の市販用ストロー使用，水深 $3 \mathrm{~cm}$ ), (3)八ミング を行った。ささらに毎日 5 分ほどで行える(2)(3)の内容を 自宅練習として課した。なお，自宅課題は十分遂行で

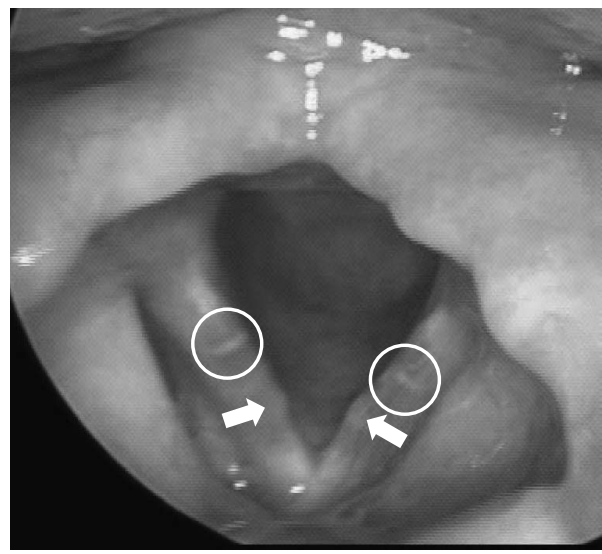

図 3 音声治療後の喉頭所見 音声治療前の喉頭所見と同様に声帯結節（矢 印で示す部分)，竹節様の病変（丸で囲った 部分）が認められた。

きた

音声治療後の結果 : 音声治療後の喉頭内視鏡検査で は，声帯結節ならびに竹節状の結節は音声治療前と比 べ，出現位置も含め著変を認めなかった（図 3)。ス トロボスコピー検査において, 発声時の声帯前後径の 短縮は以前と同様であったが，声帯粘膜波動の増幅が 見られた。声带結節を境にした声帯前方も振動が見ら れ，前方も後方もほぼ同じ周期での振動で，膜様部中 央が最も振動していた（図 2B）。聴覚心理的評価は G1R1B1A0S0，音響分析による PPQ は 0.36\%，APQ は 2.03\%，NHR は 0.16，主観的評価である VHI-10 も 5 点に改善した。MPT は 13.5 秒で, 音声治療前なら 
びに後も女性の平均的な MPTに比べ低いが, 音声治 療前・後も異常值ではなかった8). MFR は $211 \mathrm{ml}$ $\sec$ で音声治療前から正常值で音声治療後も大きく正 常值から逸脱していなかった8）(表 1).

\section{考察}

自己免疫疾患例の喉頭病変の一つに竹節状声帯があ

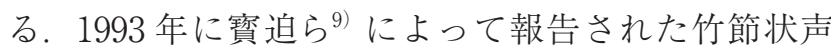
帯に扔ける帯状の隆起性病変は声帯粘膜下に発現する 免疫複合体の沈着物と推測されており, その多くが声 帯粘膜波動の大きい両声带膜様部中央に発現すると報 告されている1,10).

Hosako-Naito ら ${ }^{1)}$ は, 声帯膜様部中央に発現する要 因は両声帯の接触刺激 (contact) によるものではなく, 声帯の振動様式そのものの影響を受け，免疫複合体が 中央に集合し沈着するためという仮説を立てている. すなわち, 複数のビーズが通されている弦を強く張っ て弾くと,その弦の振動によって,ビーズは中央に寄っ て来る現象に似ているというものである。本症例の場
合，竹節様の結節は声带膜様部中央には存在せず，そ れとは別に存在する声带結節と声帯突起のほぼ間部 に存在していた，本症例に扮ける竹節様結節の発現機 序は，職場環境や子育てによる声の酷使によってまず 声帯結節が膜様部中央に出現し，そのため声带結節の ある声帯膜様部中央と声帯突起のほぼ中間部の振動が 大きくなり，その中間部に免疫複合体が沈着して竹節 様の病変が発現したと推測すると説明がつく.

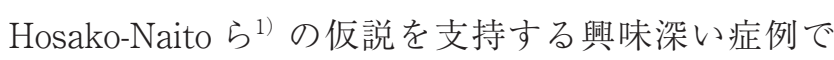
あった。

また, 竹節状声帯に対する治療法は外科的切除, 又 テロイド療法 (内服療法, 声带内注射), 音声治療が あるが, 治療法は現段階では確立されていない3, 10-12). 一方，竹節状声帯が認められた過去の報告例（表 2) では，声を多用する職業に携わる例が散見されてい る 1,2,9-11,13-16). Hosako-Naito, Murano らは竹節状の結 節の成因は声の酷使とも関連性があると述べてお $\eta^{1,2)}$, 外科的手術等で竹節状の結節が消失, つまり 器質性要因が解消されたとしても, 発話量の減少や過

表 2 竹節状声帯が認められた過去の報告例

\begin{tabular}{|c|c|c|c|c|c|c|c|c|}
\hline & 発行年 & 病 名 & 声の濫用 & 治 療 & 嗄声改善 & 病変 & 再発 & 再発後の治療 \\
\hline 寶迫ら & 1993 & SLE & $\bigcirc$ & 外科的切除術 & $\bigcirc$ & 消失 & - & \\
\hline 西成田ら & 1995 & UCTS & 不明 & ステロイド内服治療 & 0 & 消失 & - & \\
\hline Tsunoda et al. & 1996 & SLE & 不明 & ステロイド内服治療 & 0 & 消失 & - & \\
\hline Hosako-Naito et al. & 1999 & $\begin{array}{c}\text { SLE } \\
\text { リウマチ } \\
\text { PSS } \\
\text { 免疫抗体上昇 }\end{array}$ & $\begin{array}{l}0 \\
0 \\
0 \\
0\end{array}$ & $\begin{array}{c}\text { 外科的切除術 } \\
\text { 外科的切除術 } \\
\text { 外科的切除術 } \\
\text { 不明 }\end{array}$ & $\begin{array}{c}\bigcirc \\
\bigcirc \\
\bigcirc \\
\text { 不明 }\end{array}$ & $\begin{array}{l}\text { 消失 } \\
\text { 消失 } \\
\text { 消失 } \\
\text { 不明 }\end{array}$ & $\begin{array}{l}\text { 一 } \\
\text { 有 } \\
\text { - } \\
\end{array}$ & 外科的切除 \\
\hline Murano et al. & 2001 & $\begin{array}{c}\text { SLE } \\
\text { Sjogren syn. }\end{array}$ & ${ }^{\circ}$ & $\begin{array}{l}\text { ステロイド内服治療 } \\
\text { ステロイド内服治療 }\end{array}$ & $0^{\circ}$ & $\begin{array}{l}\text { 不明 } \\
\text { 不明 }\end{array}$ & $\begin{array}{l}\text { 有 } \\
\text { 有 }\end{array}$ & $\begin{array}{c}\text { 不明 } \\
\text { 声の衛生指導 }\end{array}$ \\
\hline Immerman et al. & 2007 & リウマチ & $\bigcirc$ & $\begin{array}{c}\text { ステロイド内服治療と } \\
\text { 沈黙療法 }\end{array}$ & $\bigcirc$ & 残存 & - & \\
\hline Hilgert et al. & 2008 & $\begin{array}{l}\text { MCTD } \\
\text { MCTD } \\
\text { RA }\end{array}$ & $\begin{array}{l}\text { 不明 } \\
\text { 不明 }\end{array}$ & $\begin{array}{c}\text { 音声治療と } \\
\text { ステロイド内服治療 } \\
\text { 音声治療と } \\
\text { ステロイド内服治療 } \\
\text { 音声治療 }\end{array}$ & $\begin{array}{l}\triangle \\
\times\end{array}$ & $\begin{array}{l}\text { 残存 } \\
\text { 不明 } \\
\text { 残存 }\end{array}$ & $\begin{array}{l}- \\
- \\
-\end{array}$ & \\
\hline Li et al. & 2010 & $\begin{array}{l}\text { ANA 抗核抗 } \\
\text { 体上昇 }\end{array}$ & $\bigcirc$ & 外科的切除 & 0 & 消失 & - & \\
\hline Malinvaud et al. & 2013 & SLE & 0 & ステロイド内服治療 & $\triangle$ & 残存 & - & \\
\hline Schwemmle et al. & 2013 & MCTD & 不明 & ステロイド声帯内注射 & $\times$ & 不明 & 有 & $\begin{array}{c}\text { 外科的切除術と } \\
\text { 音声治療 }\end{array}$ \\
\hline Imaizumi et al. & 2016 & SLE & 0 & ステロイド声帯内注射 & 0 & 縮小 & 無 & \\
\hline 白井ら & 2017 & 強直性脊椎炎 & $\bigcirc$ & $\begin{array}{c}\text { 音声治療 } \rightarrow \\
\text { 生物学的製剂投与 }\end{array}$ & ○ & 消失 & - & \\
\hline
\end{tabular}

SLE：全身性エリテマトーデス, UCTS：診断の確定しえない膠原病, PSS：全身性強皮症, Shogren syn. : シェーグレン症 候群, MCTD：混合性結合組織症 
緊張性発声の是正, つまり機能性要因が解消されなけ れば，再発のリスクがあるとわれわれは考えた。 Hilgertらも同様の考えを示唆した ${ }^{14)}$. そのため, 機 能性要因の解消を目指して, 今回, 誤った発声の様式 の是正, 過緊張性発声の改善, 発声効率の促進を目的 として音声治療を実施した。 また, 本症例の場合, 声 带結節も合併しており, 声带結節に対しても声の衛生 指導を含む音声治療は病変の消失，縮小だけでなく再 発の予防にもなりうるため ${ }^{4)}$, 上記の治療方針を実施 した。 そして, 結果的に声带粘膜波動が増大し嗄声を 軽減させることができ, 症例の満足度にもつながった。 今回，われわれが経験した症例は音声治療によって良 好な結果が得られたが，音声治療では竹節状の結節へ の直接的な効果は期待しにくく, やはり Schwemmle らも述べるように竹節状の結節の消失・軽減には外科 的切除やステロイド療法の実施が最も有効であると考 えられる17. Schwemmle らはさらに声質を高めるた めに外科的切除やステロイド声带内注射実施後もしく はこれらの治療法と並行して音声治療の実施の重要性 を述べている。われわれとしては声質を高めるという 目的だけでなく，外科的切除やステロイド療法だけで は竹節状の結節のリスク因子である機能的な背景が改 善されないと推測した。そのため, 特に声の酷使や過 緊張発声などの機能性要因を合併する竹節状声带の治 療に際しては，再発のリスクを抑制させるため，外科 的切除やステロイド療法を行う場合でも，並行して音 声治療を実施することが重要だと考えた。

\section{まと め}

SLE を基礎疾患として有した症例に生じた声帯結 節と竹節状の結節の発現機序について, Hosako-Naito らの仮説を支持するものだったままた，本症例に対し て音声治療を治療方針として選択したところ，音声治 療後，喉頭所見上，声带結節や竹節状の結節に顕著な 変化は見られなかったが，声帯粘膜波動の増大が認め られ，音響分析検査ならびに自覚的評価も改善され， 症例自身の満足度が上がった，音声治療は，竹節状声 帯への直接的な効果は期待できないが, 病変の出現の リスク因子である機能性要因（声の酷使，過緊張性発 声）の解消手段として治療方針に含めることが望まし いと考えられた。

利益相反自己申告：申告すべきものなし．

\section{文献}

1) Hosako-Naito Y, Tayama N, Niimi $\mathrm{S}$, et al: Diagnosis and physiopathology of laryngeal deposits in autoimmune disease. ORL J Otorhinolaryngol Relat Spec, 61 (3): 151157, 1999.

2) Murano E, Hosako-Naito Y, Tayama N, et al: Bamboo node: primary vocal fold lesion as evidence of autoimmune disease. J Voice, 15 (3): 441-450, 2001.

3) Griffiths B, Mosca M and Gordon C: Assessment of patients with systemic lupus erythematosus and the use of lupus disease activity indices. Best Pract Res Clin Rheumatol, 19 (5): 685-708, 2005.

4）四倉淑枝：声带結節に対する音声治療の研究. 日耳鼻, 90 (9) : 1387-1401, 1987.

5) McCrory E: Voice therapy outcomes in vocal fold nodules: a retrospective audit. Int J Lang Commun Disord, 36 Suppl: 19-24, 2001.

6) Guzman M, Jara R, Olavarria C, et al: Efficacy of water resistance therapy in subjects diagnosed with behavioral dysphonia: A randomized controlled trial. J Voice, 31 (3): 385.e1-385.e10, 2017.

7) Guzman M, Laukkanen AM, Traser L, et al: The influence of water resistance therapy on vocal fold vibration: a high-speed digital imaging study. Logoped Phoniatr Vocol, 42 (3): 99-107, 2017.

8）生井友紀子：検查一情報の収集一. ST のための音声障害 診療マニュアル(廣瀬 肇監修), インテルナ出版, 東京, 26 頁, 2008 .

9）寶迫 雪, 中村雅一, 田山二朗, 他：SLE 患者に認めら れた特異な喉頭所見。喉頭，5 (2)：171-175， 1993.

10) Li L, Saigusa H, Nakazawa $Y$, et al: A pathological study of bamboo nodule of the vocal fold. J Voice, 24 (6): 738741, 2010.

11) Malinvaud D, Mukundan S, Crevier-Buchman L, et al: Glottic bamboo nodules from systemic lupus erythematosus. Ann Otol Rhinol Laryngol, 122 (8): 496499, 2013.

12）梅崎俊郎：竹節状声帯. 耳鼻と臨床, 56 (5)：234-236, 2010.

13) Immerman $S$ and Sulica L: Bamboo nodes. Otolaryngol Head Neck Surg, 137 (1): 162-163, 2007.

14) Hilgert $\mathrm{E}$, Toleti $\mathrm{B}$, Kruger $\mathrm{K}$, et al: Hoarseness due to bamboo nodes in patients with autoimmune diseases: a review of literature. J Voice, 22 (3): 343-350, 2008.

15) Imaizumi $M$, Tada $Y$, Okano $W$, et al: Effectiveness of steroid injections for bamboo nodules: A case report. Ear Nose Throat J, 95 (4-5): E21-E23, 2016.

16）白井裕美子, 土師知行, 末廣篤, 他: 強直性脊椎炎を基 礎疾患とする竹節状声帯例。音声言語医学, 58 : 346-349, 2017.

17) Schwemmle C, Kreipe HH, Witte T, et al: Bamboo nodes associated with mixed connective tissue disease as a cause of hoarseness. Rheumatol Int, 33: 777-781, 2013.

別刷請求先：=606-8507 京都市左京区聖護院川原町 54 京都大学大学院医学研究科耳鼻咽㑨科・頭頸 部外科

近藤香菜子 